\title{
Achieving Durable Resistance Against Plant Diseases: Scenario Analyses with a National-Scale Spatially Explicit Model for a Wind-Dispersed Plant Pathogen
}

\author{
Marjolein Elisabeth Lof, Claude de Vallavieille-Pope, and Wopke van der Werf
}

First and third authors: Wageningen University, Centre for Crop Systems Analysis, P.O. Box 430, 6700 AK Wageningen, The Netherlands; and second author: INRA UMR 1290 BIOGER, BP01, 78850 Thiverval-Grignon, France.

Accepted for publication 3 January 2017.

\begin{abstract}
Genetic resistance in crops is a cornerstone of disease management in agriculture. Such genetic resistance is often rapidly broken due to selection for virulence in the pathogen population. Here, we ask whether there are strategies that can prolong the useful life of plant resistance genes. In a modeling study, we compared four deployment strategies: gene pyramiding, sequential use, simultaneous use, and a mixed strategy. We developed a spatially explicit model for France and parameterized it for the fungal pathogen Puccinia striiformis f. sp. tritici (causing wheat yellow rust) to test management strategies in a real-

emerge by mutation. Deploying single-gene-resistant varieties concurrently with the pyramided variety eroded the durability of the gene pyramid. We found that continuation of deployment of varieties with broken-down resistance prolonged the useful life of simultaneous deployment of four single-gene-resistant varieties versus sequential use. However, when virulence was already present in the pathogen population, durability was low and none of the deployment strategies had effect. These results provide guidance on effective strategies for using resistance genes in crop protection practice.
\end{abstract} istic spatial setting. We found that pyramiding two new resistance genes in one variety was the most durable solution only when the virulent genotype had to
Additional keywords: gene-for-gene.
Resistant varieties are widely used for the management of pests and diseases. Selection pressure for resistance-breaking genotypes in agricultural systems is strong (de Vallavieille-Pope et al. 2012; Parlevliet 2002; Stuckenbrock and McDonald 2008). In practice, the effectiveness of new qualitative resistance genes (i.e., major resistance genes that operate on a gene-for-gene basis with avirulence genes in the pathogen) (De Wit 1997; Flor 1971) is therefore often short lived (McDonald and Linde 2002; Parlevliet 2002; Zhan et al. 2014). When resistance is broken, growers adopt varieties with new resistance genes, resulting in a "boom and bust" cycle of increase in use of a resistant variety (the boom), followed by the emergence and selection for a resistance-breaking pathogen phenotype (the bust), resulting in replacement of varieties with broken resistance by one or more varieties with new resistance traits. Boom and bust cycles have been described for cereal rusts and powdery mildew (de VallavieillePope et al. 2012; Kolmer 1996; Wolfe and McDermott 1994). The limited durability of qualitative resistance is a major problem in plant breeding for pathogen resistance (McDonald and Linde 2002). Breeding a new, high-yielding variety with new resistance genes takes time and the genetic pool for new resistance genes is limited. Therefore, it is important to deploy new resistance genes in such a way that the useful life is as long as possible.

Modeling studies on durability of qualitative resistance have shown that stacking two resistance genes is generally more durable than using two single-resistance gene varieties. Generally, no difference is found in durability between varieties with single resistance when they are used sequentially (i.e., the second gene is first used when the first gene

Corresponding author: M. Lof; E-mail address: marjolein.lof@wur.nl

*The $\boldsymbol{e}$-Xtra logo stands for "electronic extra" and indicates that one supplementary file is published online.

This article is in the public domain and not copyrightable. It may be freely reprinted with customary crediting of the source. The American Phytopathological Society, 2017. is broken), in alternation (e.g., in alternate years), or simultaneously (with part of the fields planted with a variety with one of the genes, another part with a variety with another gene, and part with a variety without resistance) (Wolfe and Barrett 1977; Leonard and Czochor 1980; Kiyosawa 1982). Nearly all models of plant pathogen evolution assume stabilizing selection. Stabilizing selection assumes that there are fitness costs associated with loss of avirulence (Van der Plank 1968). This would imply that pathogen genotypes are as simple as possible, without redundant virulence genes (Van der Plank 1968). Fitness costs associated with avirulence are very difficult to measure empirically (Leach et al. 2001; Mundt et al. 2002). Review of the literature showed that the loss of some avirulence genes is associated with a reduction in fitness whereas, for others, no fitness costs have been detected (Leach et al. 2001). Furthermore, literature review showed that several crop pathosystems occur with several to many redundant virulence genes (Parlevliet 1981). Thus, stabilizing selection is not a general phenomenon; therefore, we studied which deployment strategy is most effective in managing pathogen evolution in the absence of stabilizing selection. Furthermore, we included spatial dispersal of the pathogen. Spatial dispersal ability of new pathogen genotypes is recognized as one of the pillars of their evolutionary potential (McDonald and Linde 2002).

Wind-dispersed pathogen spores can travel long distances of several hundred kilometers (Zadoks 1961; Brown and Hovmøller 2002; Hovmøller et al. 2002). The effect of deployment of resistant varieties has only been studied at a small scale (ranging from tens of meters to several kilometers) (Sapoukhina et al. 2009; Sapoukhina et al. 2010; Skelsey et al. 2010) and, until now, has not been studied on a national scale. It is not practical to set up an experiment at the national scale; therefore, we used modeling to test four management strategies at a large spatial scale and in a realistic spatial setting of the host based on land cover data. In this study, we tested the effect of spatial deployment and variety choice at a national scale on the evolution and spread of an airborne resistance-breaking pathogen genotype at a much larger spatial scale; namely, the scale of the whole area of France. The large spatial scale is relevant because plant pathogens spread over large 
distances, and resistance-breaking types emerged or selected in one area may rapidly spread to much wider areas. Scenario testing was done for France and the model is parameterized to reflect evolutionary dynamics and spread of a wind-dispersed cereal rust.

To parameterize the model, we used data on seasonal distribution of the pathogen Puccinia striiformis f. sp. tritici, cause of yellow rust on wheat, in France (de Vallavieille-Pope et al. 2012). P. striiformis is a pathogen that reproduces asexually. Up to the arrival of the new genotypes in 2011, the population in Denmark, the United Kingdom, Germany, and France was effectively one clonal population (Hovmøller et al. 2002). However, even though it is a clonal population, the evolutionary potential is high. New resistant varieties can be broken down in only a couple of years, sometimes even when still in the multiplication phase premarket (de Vallavieille-Pope et al. 2012).

In this modeling study, we explored the effects of resistance gene deployment strategy and pathogen life-cycle components on the useful life of resistance genes to find the most durable deployment strategy. We studied four gene deployment strategies for two resistance genes: (i) sequential use of two single-gene-resistant varieties (i.e., using a single variety until it is broken), (ii) stacking of two resistance genes within one variety (pyramiding), (iii) simultaneous use of two single-gene-resistant varieties, and (iv) and a mixed strategy, in which a variety with stacked resistance genes is used concurrently with two varieties with single resistance genes.

Deploying multiple single-gene-resistant varieties at the same time might dilute the chance that inoculum will find a suitable host and, thereby, have a positive effect on the useful life. Therefore, we furthermore compared two deployment strategies for the use of four resistance genes: sequential use of four single-gene-resistant varieties and simultaneous use of four single-gene-resistant varieties. Crop rotation can reduce disease pressure by dilution of inoculum from one growing season to the next, especially for pathogens that can only disperse for short distances and, thus, depend on local inoculum (Trivedi and Barker 1986; Abawi and Widmer 2000). Here, we studied whether crop rotation, by removing the chance of infection of newly planted hosts by lesions that survived on volunteers (i.e., selfsown wheat) in the field, can affect durable life of resistance even if pathogens depend less on local inoculum because of long-distance spore dispersal.

Whether a virulent genotype is already present in the population or first has to emerge by mutation might affect the effectiveness of gene deployment strategies. Therefore, we tested all deployment strategies for two situations: (i) all virulence genes are already present in the pathogen population, albeit in a very low fraction of the population, such that selection for virulence in the pathogen population starts immediately; or (ii) virulence is not present from the start and has to emerge by mutation before selection for virulence will start.

\section{MATERIALS AND METHODS}

We developed a spatiotemporal population model for the dispersal and reproduction of avirulent and virulent pathogens in a landscape of susceptible and resistant hosts at the scale of France. We modeled a gene-for-gene relationship in which a pathogen can only infect a resistant host when the pathogen has lost its avirulence gene for that specific resistance (De Wit 1997; Flor 1971). The virulent genotype of the pathogen ("virulent pathotype") can infect both hosts in the susceptible fields and in the resistant fields and, thus, reproduce in all host fields, whereas the avirulent genotype of the pathogen ("avirulent pathotype") can infect only the hosts in the susceptible fields and, thus, only reproduce in fields containing the susceptible host. Our model is based on the dynamics of $P$. striiformis $\mathrm{f}$. sp. tritici, which causes yellow rust on wheat. $P$. striiformis reproduces asexually and is biotrophic; it infects living plant tissue.

We used integro-difference equations (Neubert et al. 1995; Powell 2001; Powell et al. 1998) to model pathogen population dynamics and spread. In the integro-difference approach, dispersal and population dynamics are treated as separate processes. Each generation starts with spore dispersal and ends with spore production. The spores in the first generation originate from lesions on plant material that survived in the field. Three steps are distinguished: (i) dispersal of avirulent and virulent spores $\left(S_{\mathrm{A}}\right.$, and $S_{\mathrm{V}}$, respectively) that were produced in the previous generation, (ii) formation of avirulent and virulent lesions ( $L_{\mathrm{A}}$, and $L_{\mathrm{V}}$, respectively), and (iii) production of new spores. The dispersal process is modeled with dispersal kernels (i.e., spatial probability distributions of the number of deposited spores at different distances from the source). We assume that most spores will remain in the field (one grid cell in the model of 500 by $500 \mathrm{~m}$ ). Only a fraction $(q)$ of the newly produced spores will disperse.

Step I, spore dispersal. In step I, a fraction $(q)$ of the spores that were produced in the previous generation disperses. The number of spores in a field after dispersal is the sum of the newly arrived spores and the fraction $(1-q)$ of spores that has remained in the field. The number of avirulent spores on susceptible and resistant hosts and the number of virulent spores on susceptible and resistant hosts is calculated as:

$$
\begin{aligned}
S_{A, S}(x, y, t)= & \iint_{x^{\prime}} q S_{y^{\prime}}\left(x^{\prime}, y^{\prime}, t-1\right) K_{2 D t}\left(x-x^{\prime}, y-y^{\prime}\right) d x^{\prime} d y^{\prime} \\
& +(1-q) S_{A, S}(x, y, t-1) \\
S_{A, R}(x, y, t)= & \iint_{x^{\prime}} q S_{y^{\prime}}\left(x^{\prime}, y^{\prime}, t-1\right) K_{2 D t}\left(x-x^{\prime}, y-y^{\prime}\right) d x^{\prime} d y^{\prime} \\
S_{V, S}(x, y, t)= & \int_{x^{\prime}} \int_{y^{\prime}} q\left(S_{V, S}\left(x^{\prime}, y^{\prime}, t-1\right)\right. \\
& \left.+S_{V, R}\left(x^{\prime}, y^{\prime}, t-1\right)\right) K_{2 D t}\left(x-x^{\prime}, y-y^{\prime}\right) d x^{\prime} d y^{\prime} \\
& +(1-q) S_{V, S}(x, y, t-1) \\
S_{V, R}(x, y, t)= & \int_{x^{\prime}} \int_{y^{\prime}} q\left(S_{V, S}\left(x^{\prime}, y^{\prime}, t-1\right)\right. \\
& \left.+S_{V, R}\left(x^{\prime}, y^{\prime}, t-1\right)\right) K_{2 D t}\left(x-x^{\prime}, y-y^{\prime}\right) d x^{\prime} d y^{\prime} \\
& +(1-q) S_{V, R}(x, y, t-1)
\end{aligned}
$$

Here, $x^{\prime}$ and $y^{\prime}$ denote all source locations contributing to the deposition of propagules at target location $(x, y)$ and $t$ denotes the pathogen generation. The spatial probability density kernel, $\mathrm{K}_{2 \mathrm{Dt}}$, specifies where spores that are produced in the previous pathogen generation are deposited. As a dispersal model, we used a 2Dtdistribution with two parameters: a length scale $u$ in kilometers and a shape parameter $v$ (Clark et al. 1999; Robinet et al. 2012)

$$
K_{2 D t}(x, y)=\frac{1}{u^{2} \pi \nu} \frac{\Gamma\left(\frac{\nu+1}{2}\right)}{\Gamma\left(\frac{\nu-1}{2}\right)}\left(1+\frac{1}{\nu} \frac{x^{2}+y^{2}}{u^{2}}\right)^{-\frac{\nu+1}{2}}
$$

The 2Dt-distribution is a flexible dispersal model. Depending on the "degrees of freedom" parameter $v$, this model can approach a thintailed normal distribution $(v \rightarrow \infty)$ or a fat-tailed Cauchy distribution $(v \rightarrow 1)$ enabling long-distance dispersal. Changing the length scale $u$ reflects smaller or longer dispersal distances, and changing $v$ changes the frequency of long-distance dispersal (Robinet et al. 2012).

We assumed that the actual population size in a field after the first step is a realization from a Poisson process with the expected number of spores equal to the number of avirulent spores, $S_{\mathrm{A}}$, respectively, virulent spores, with $S_{\mathrm{V}}$, at location $(x, y)$ after dispersal. 
Step II, lesion formation. Next, the spores in the field formed new lesions. We modeled a carrying capacity for the number of lesions per wheat field. The total number of lesions in a field $\left(L_{\text {tot }}\right)$ consists of latent, sporulating, and dead lesions. We did not model dead lesions explicitly, but considered the fact that lesions from previous generations continue to occupy space on the leaf which cannot be infected by new lesions. However, only new lesions produce spores. When the total number of lesions in a field approaches the carrying capacity $(K)$, the formation of new lesions is reduced based on a logistic feedback term. New avirulent lesions $\left(L_{\mathrm{A}, \mathrm{S}}\right)$ are only formed in susceptible host fields. Therefore, the density of new avirulent lesions in susceptible compared with resistant host fields is:

$$
\begin{gathered}
L_{A, S}(x, y, t)=S_{A, S}(x, y, t)\left(1-\frac{S_{A, S}(x, y, t)+S_{V, S}(x, y, t)+L_{t o t, S}(x, y, t-1)}{K}\right) \\
L_{A, R}(x, y, t)=0
\end{gathered}
$$

where $S_{A, S}(x, y, t)$ is the density of avirulent spores deposited in susceptible fields, and the righthand term represents the effect of carrying capacity. There is no infection probability included in equation 4 because the loss of spores due to failure to infect is accounted for in the calculation of the number of spores per lesion. Produced spores are therefore "effective" spores, on the condition that they are deposited in a compatible host field (see below). New virulent lesions can be formed in both susceptible and resistant host fields. Both avirulent and virulent spores can infect the susceptible host; therefore, the logistic feedback term of the susceptible host depends on the total number of lesions already present and both the deposited avirulent spores and the deposited virulent spores (equations $4 \mathrm{a}$ and 5a). Avirulent spores are unable to infect a resistant host; therefore, the logistic feedback term of the resistant host depends only on the deposited virulent spores and the previously formed lesions (equation $5 \mathrm{~b}$ ).

$$
L_{V, S}(x, y, t)=S_{V, S}(x, y, t)\left(1-\frac{S_{A, S}(x, y, t)+S_{V, S}(x, y, t)+L_{t o t, S}(x, y, t-1)}{K}\right)
$$

$L_{V, R}(x, y, t)=S_{V, R}(x, y, t)\left(1-\frac{S_{V, R}(x, y, t)+L_{t o t, R}(x, y, t-1)}{K}\right)$

After the new lesions are formed, the total number of lesions in the susceptible and resistant fields ( $L_{\mathrm{tot}, \mathrm{S}}$ and $L_{\mathrm{tot}, \mathrm{R}}$ respectively, is updated:

$$
L_{t o t, S}(x, y, t)=L_{t o t, S}(x, y, t-1)+L_{A S}(x, y, t)+L_{V S}(x, y, t)
$$

\begin{tabular}{|c|c|c|}
\hline Name & Description & Value \\
\hline$\lambda$ & $\begin{array}{l}\text { Net multiplication factor; number of } \\
\text { effective spores per lesion }\end{array}$ & 35 \\
\hline$q$ & Fraction of pathogen spores leaving the field & 0.05 \\
\hline$\beta$ & $\begin{array}{l}\text { Initial fraction of virulent spores in the } \\
\text { pathogen population }\end{array}$ & $10^{-4}$ \\
\hline$\theta_{\mathrm{e}}$ & $\begin{array}{l}\text { Threshold fraction of virulent genotypes in } \\
\text { the pathogen population }\end{array}$ & 0.45 \\
\hline$m$ & $\begin{array}{l}\text { Chance that a newly mutated spore becomes } \\
\text { one of the } \lambda \text { daughter lesions }\end{array}$ & $10^{-9}$ \\
\hline$K$ & Carrying capacity wheat field & $1.5 \times 10^{10}$ \\
\hline$s$ & Fraction of between season survival & $10^{-3}$ \\
\hline$u$ & Length scale of pathogen dispersal (in km) & 25 \\
\hline$\nu$ & $\begin{array}{l}\text { Shape parameter of dispersal model, affects } \\
\text { frequency of long-distance dispersal }\end{array}$ & 5 \\
\hline
\end{tabular}

TABLE 1. Parameter values of model at national scale

$$
L_{t o t, R}(x, y, t)=L_{t o t, R}(x, y, t-1)+L_{V R}(x, y, t)
$$

Step III, spore production. At the end of a pathogen generation, $t$ new spores are produced at a rate of $\lambda$ per lesion:

$$
\begin{aligned}
& S_{A, S}(x, y, t)=\lambda L_{A, S}(x, y, t) \\
& S_{A, R}(x, y, t)=0 \\
& S_{V, S}(x, y, t)=\lambda L_{V, S}(x, y, t) \\
& S_{V, R}(x, y, t)=\lambda L_{V, R}(x, y, t)
\end{aligned}
$$

In this model, the reproduction factor $\lambda$ represents the expected daughter lesions per mother lesion (Supplementary File S1). Therefore, these are "effective" spores if they are deposited on a host field. When virulence has to emerge by mutation, there is a small probability $m$ that a newly produced spore from an avirulent lesion in a susceptible field becomes virulent ( $m$ takes into account the probability that a spore mutates and the probability that the mutated spore is one of the daughter lesions). In this case, equations $7 \mathrm{a}$ and $8 \mathrm{a}$ from the above set of equations become:

$$
\begin{aligned}
& S_{A, S}(x, y, t)=\lambda L_{A, S}(x, y, t)-\operatorname{Pois}\left(m \lambda L_{A, S}(x, y, t)\right) \\
& S_{V, S}(x, y, t)=\lambda L_{V, S}(x, y, t)+\operatorname{Pois}\left(m \lambda L_{A, S}(x, y, t)\right)
\end{aligned}
$$

In this study, we only considered the mutation from avirulence to virulence, because we assumed that this will influence the emergence of a mutant that has a selective advantage, and that this will influence population dynamics more than the emergence of a mutant that has a selective disadvantage (i.e., a mutant from virulence to avirulence). Some resistance genes in the host are associated with fitness costs in the pathogen (Bahri et al. 2009; de Vallavieille-Pope et al. 2012). However, there are examples (even within the same pathogen) where virulence in the pathogen genotype has a neutral effect or even a fitness benefit (Bahri et al. 2009; de Vallavieille-Pope et al. 2012). Therefore, we decided not to include fitness cost for virulence in the model. The description and the values of the model parameters are given in Table 1.

Simulation set-up. Management strategies. We compared the useful life of two resistance genes and four strategies for gene deployment: (i) sequential use, in which two single-gene-resistant varieties are used in sequence; (ii) pyramiding, in which two resistance genes are stacked in one variety; (iii) simultaneous use, in which two singlegene resistance varieties are deployed simultaneously; and (iv) a mixed strategy, in which a stacked variety with two resistance genes is deployed concurrently with two varieties with the same resistance genes used in single-gene-resistant varieties. For sequential use, a single-gene-resistant variety is used until resistance is considered broken down (i.e., when the fraction of virulent spores in the pathogen population is above the threshold $\theta_{\mathrm{e}}$ ) and is then replaced with a new single-gene-resistant variety.

Furthermore, we compared sequential use and simultaneous use for the deployment of four single-gene-resistant varieties. When four resistant varieties are deployed simultaneously, it is possible that one variety is broken down while the others are still effective. We considered three possibilities after a resistant variety is broken down. The first is to remove the variety and replace it by a singlegene-resistant variety that has not been used before. This would result in more than four resistant varieties being available in the period until the fourth resistant variety is broken down; therefore it, is not possible to measure the durable life of four resistance genes in this strategy. The second is to remove the variety and equally distribute the remaining resistant varieties over the resistant fields. The third is to continue the use of the variety of which resistance is 
broken down. For the above deployment strategies, we also studies the effect of fraction of resistant host on useful life.

Effect of deployment parameters. For each management strategy, we tested fractions of resistant hosts from 0.1 to 0.9 in steps of 0.1 . The remaining fraction of wheat fields was planted with a susceptible variety. Furthermore, for each management strategy for deployment of two resistance genes, we tested whether crop rotation prolonged the useful life of resistance genes.

Population genetics. For each gene deployment scenario, we considered two cases: (i) virulence is already present at a low frequency at the start of the simulation, or when a new resistant variety is introduced (selection only), and (ii) virulence is not present yet and has to emerge by mutation (emergence and selection). In both cases, virulence increases in the population due to the selective advantage of the virulent over the avirulent (e.g., faster increase in numbers because they can infect a larger area).

Landscape. We ran spatial simulation scenarios at the national scale of France. As input for the dispersal model, we used the longterm and detailed dataset of isolates of $P$. striiformis $\mathrm{f}$. sp. tritici that were phenotyped for virulence in France in 1984-2012 (on average, 71 samples per year) (de Vallavieille-Pope et al. 2012). From 1985 onward, this dataset contains the name of the location (nearest village) and the name of the department in which the sample was collected. To set up a realistic spatial setting, we used detailed information on land use in France available from Corine Land Cover raster data 2006 (European Environment Agency 2012), in combination with information on the percentage of wheat used per department that was available for 1989-2013 (Agreste 2013). We allocated a fraction of the arable land per department as wheat based on the percentage of wheat per department in 2006. We divided France into cells of 500 by $500 \mathrm{~m}$. Each of these cells was considered to be either a nonhost or wheat. To generate a landscape that mimics the distribution of wheat fields in France, a percentage of the arable area in a department, equal to the percentage of wheat in that specific department, was randomly designated as a wheatgrowing area.

Simulation set-up. Each scenario covered a period of 30 growing seasons spanning 30 years. We used the same set of 30 randomly generated landscapes to compare scenarios and reduce random effects. In these landscapes, the placement of the host fields was fixed but the placement of the susceptible and resistant hosts was variable. We ran three replicates for each fraction of resistant fields.

For the simulations with crop rotation, we assumed a 3-year rotation. Three landscapes were generated and were repeatedly used in the same order 10 times. In the set of three landscapes, an arable field could be a wheat field only once at the most. If the percentage of wheat in the department was less than $33.3 \%$, then some arable fields were never deployed as wheat fields. We ran three replicates of the crop rotation simulations. We generated three sets (one for each replicate) of three landscapes and used these to compare scenarios and reduce random effects.

In all scenarios, the initial population started from 300 randomly chosen wheat fields in the first season. We selected the departments Nord, Somme, Calvados, Yvelines, Eure-et-Loir, and Côtes d'Armor as the starting departments of the initial pathogen population in the model (Supplementary File S1), because these were the departments with multiple years with early detection of yellow rust in the French data of yellow rust detections (as described above). In these departments, located at the northwest coast of France, yellow rust can already be found very early in the season. We assumed that a small fraction $(s)$ of the lesions can survive the summer on volunteers (selfsown offspring) of the crop and subsequently overwinter on sown seedlings of its host in these departments. We furthermore assumed that, in the other departments, the conditions were not suitable for both oversummer and overwinter survival.

P. striiformis in France is generally present (in detectable density) from early March, when wheat starts to grow, to mid-June, when the temperatures become too warm. $P$. striiformis has a latent period of
14 days (Milus et al. 2009) and has maximum spore production 4 days after the latent period (Rapilly 1979). We assumed that yellow rust can complete six generations from the month of first detection until mid-June, when temperature becomes high, reducing spore production.

In the model, we calculated the total number of avirulent and virulent spores in France at the end of the season $\left(S_{\mathrm{A} \text {,tot }}\right.$ and $S_{\mathrm{V} \text {,tot }}$, respectively) and used these to monitor the change in fraction of virulent pathotype $\theta_{\mathrm{V}}=S_{\mathrm{V} \text {,tot }} / S_{\text {tot }}$ over time, where $S_{\text {tot }}$ is the total number of spores in France $\left(S_{\mathrm{V}, \text { tot }}+S_{\mathrm{A} \text {,tot }}\right)$. For each gene deployment scenario, we determined the useful life, defined as the number of growing seasons during which the fraction of resistance-breaking genotypes $\left(\theta_{\mathrm{V}}\right)$ in the pathogen population stays below threshold $\theta_{\mathrm{e}}$. To determine the useful life for simultaneous use, or in the case of the mixed strategy, we determined the total fraction of the pathogen population that can infect a specific resistant variety. For instance, when two single-gene-resistant varieties are grown at the same time, a variety with resistance gene 1 is considered broken down when the sum of $\theta_{\mathrm{V} 1}+\theta_{\mathrm{V} 1, \mathrm{~V} 2}$ is greater than threshold $\theta_{\mathrm{e}}$. Here, $\theta_{\mathrm{V} 1}$ denotes the fraction of spores that can infect resistant variety $\mathrm{R} 1$ and $\theta_{\mathrm{V} 1, \mathrm{~V} 2}$ denotes the fraction of spores that can infect both resistant variety $\mathrm{R} 1$ and resistant variety $\mathrm{R} 2$. The same applies when four varieties are grown simultaneously; a variety with resistance gene R1 is then considered broken down if the sum of $\theta_{\mathrm{V} 1}+\theta_{\mathrm{V} 1, \mathrm{~V} 2}+\theta_{\mathrm{V} 1, \mathrm{~V} 3}+\theta_{\mathrm{V} 1, \mathrm{~V} 4}+$ $\theta_{\mathrm{V} 1, \mathrm{~V} 2, \mathrm{~V} 3}+\theta_{\mathrm{V} 1, \mathrm{~V} 2, \mathrm{~V} 4}+\theta_{\mathrm{V} 1, \mathrm{~V} 3, \mathrm{~V} 4}+\theta_{\mathrm{V} 1, \mathrm{~V} 2, \mathrm{~V} 3, \mathrm{~V} 4}$ is greater than the threshold $\theta_{\mathrm{e}}$.

\section{RESULTS}

Population dynamics. In the first pathogen generation of the "mutation and selection" scenario (i.e., when virulent inoculum was not already present), avirulent spores already reached the center of France and even a few fields in the South of France (Fig. 1), a direct consequence of the fat tails of the 2Dt-dispersal kernel (with $u=25$, $v=5$ ). However, at this stage, the density was so low (between $10^{-5}$ and $10^{-3}$ lesions $/ \mathrm{m}^{2}$ ) that they would be below the detection threshold under practical field conditions. During the growing season, the pathogen population continued to spread and rapidly increase in size. The carrying capacity was reached in many fields in the northwest of France during the fifth pathogen generation. This process is very similar each year but the exact location in which the pathogen population in the field reaches a detectable population size early in the season differed between years. The number of lesions in a field in the early season depends on chance: how many spores arrive and how many lesions are formed. After the first lesions are formed, most spores will remain in the field and form new lesions, initially resulting in a fast population growth. A field that was infected with yellow rust early in the season will be limited in lesion formation earlier than fields that were infected later. As a result, there will be a smaller population size at the start of the next growing season in that field compared with fields in northwest France that were infected later in the season. This will affect the spore availability at the beginning of the next growing season. The population dynamics described above were very similar in the selection only scenario and the mutation and selection scenario.

With sequential use of resistant hosts in the mutation and selection scenario (Fig. 2), by chance, the first mutations to virulence already appeared in the beginning of the first growing season but not in all fields with an avirulent population and only in very low numbers. For each time step, we calculated the fraction of new mutations in each field; this showed that the largest part of the spread of virulence in the population in the landscape was caused by new mutations. Mutations are most likely to occur where the avirulent population is large, because the mutants are a fraction of the newly formed spores of the avirulent population; therefore, the pattern of seasonal spread of the virulent pathogen lagged behind the increase of the avirulent population. The virulent genotype occurred in detectable levels in the fields in the northwest of France only late in the season (the fifth and sixth pathogen generation) (Fig. 2). The second year, the virulent 
population is larger and the level and detectably high population numbers are reached earlier in the season. The virulent genotypes reach the south of France, however still in numbers that are too low for detection.

When four single-gene-resistant varieties are used simultaneously, the pattern of spread of the virulent pathogen genotypes is very similar to that with sequential use; however, the total virulent population is smaller than with sequential use because, with simultaneous use, a virulent genotype can only infect the susceptible wheat fields and one-fourth of the resistant fields. This smaller host area causes dilution of inoculum as compared with sequential use and, thereby, reduces growth of the total virulent population as compared with the virulent genotype with sequential use. The spatial patterns of increase and spread differ between the different virulent

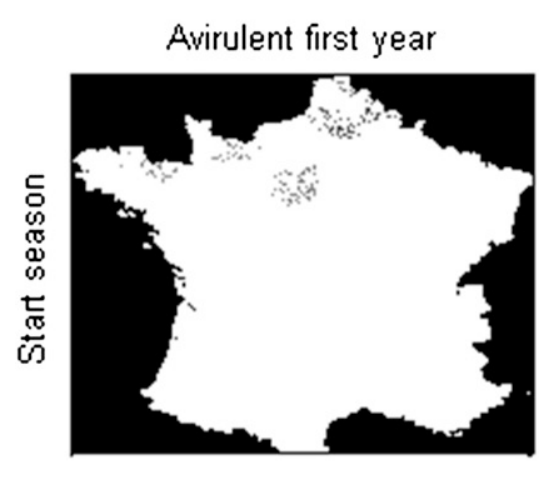

$\log \left(L_{A}\right)$

Avirulent second year

$\log \left(L_{A}\right)$

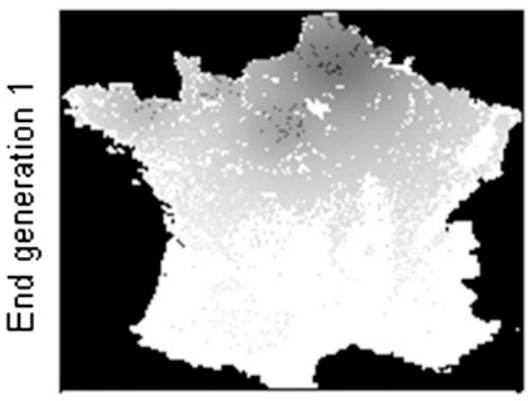

20
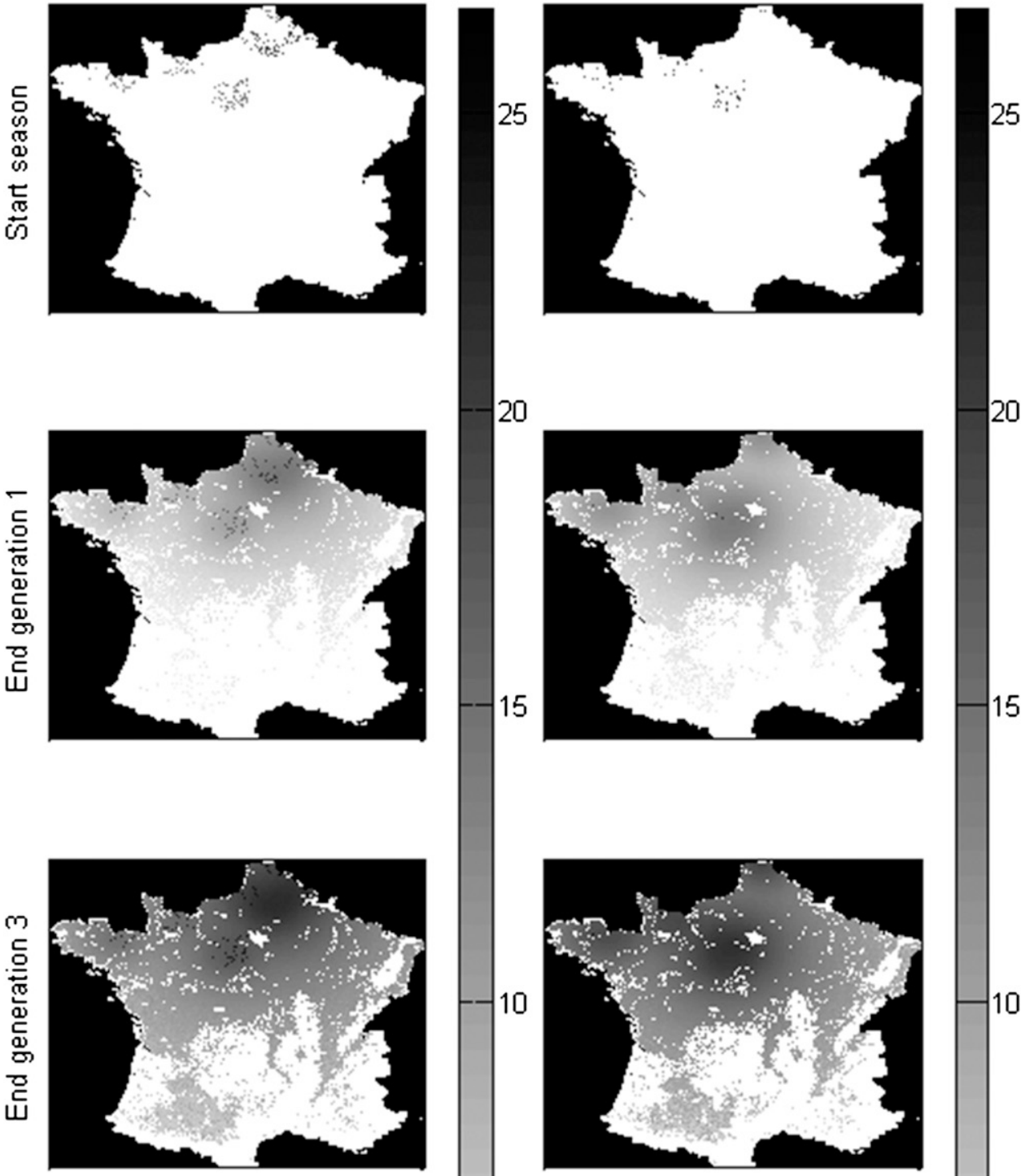

$-15$
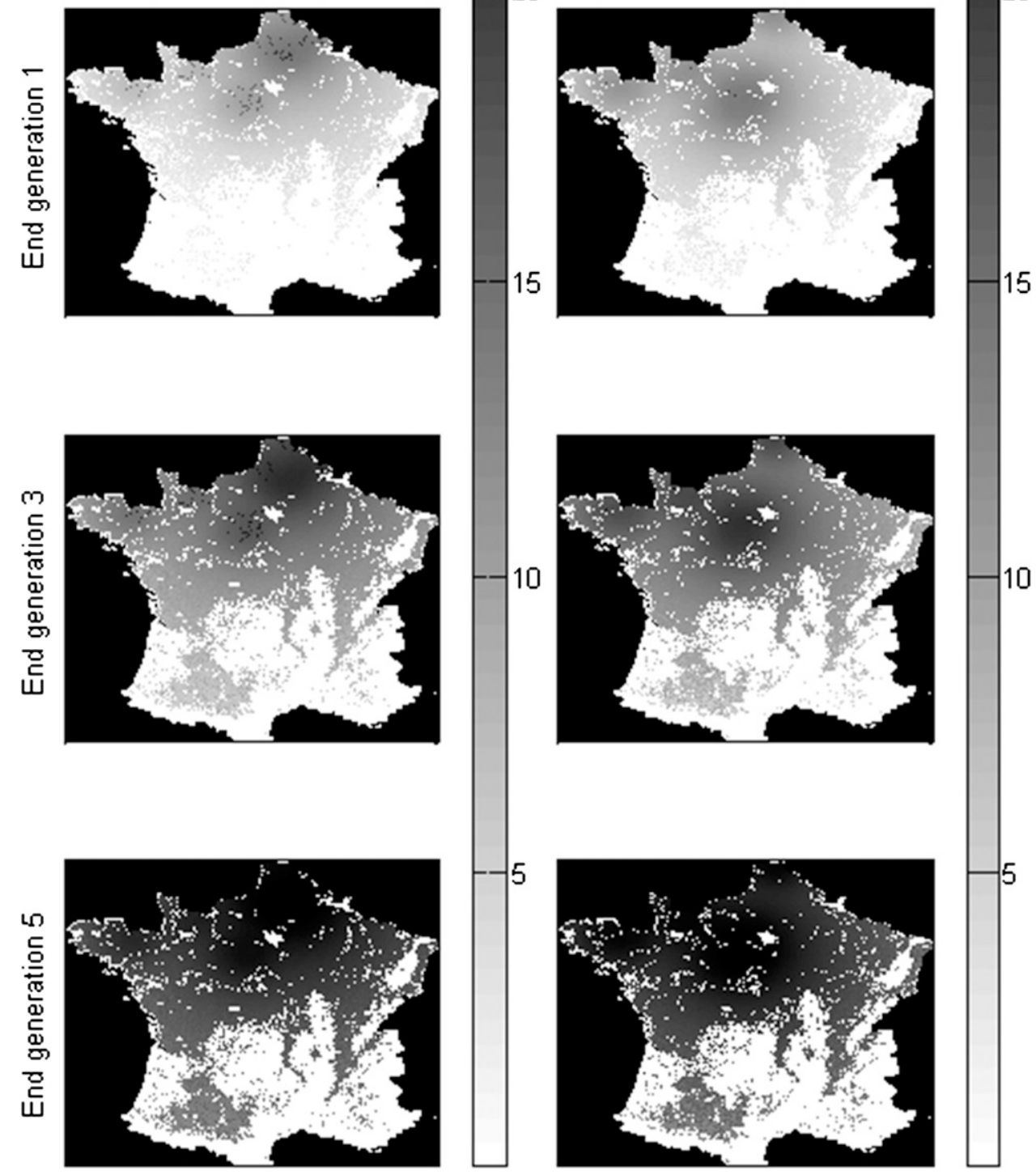

Fig. 1. Spatial and temporal dynamics of an avirulent pathogen genotype in France depicted for the first 2 years of a simulation. Results are shown for sequential use with a fraction of single-resistant hosts $=0.6$. Shaded bar depicts the number of avirulent lesions per field on a log scale; on this scale, 15 is approximately 13 avirulent lesions $\mathrm{m}^{-2}$. 
genotypes due to random effects of where a mutation appears. This affects the population size at the end of the first growing season and, consequently, the population size in the next growing season.

Useful life. In the selection-only scenario, in which virulence is already present in a very small fraction of the pathogen population at the start of the simulation, the useful life of two resistance genes was usually on the order of 2 to 6 years (depending on the fraction of resistant fields) and differences between deployment strategies were very small (Fig. 3). This picture completely changes when virulence had to emerge by mutation. In all replicate simulations
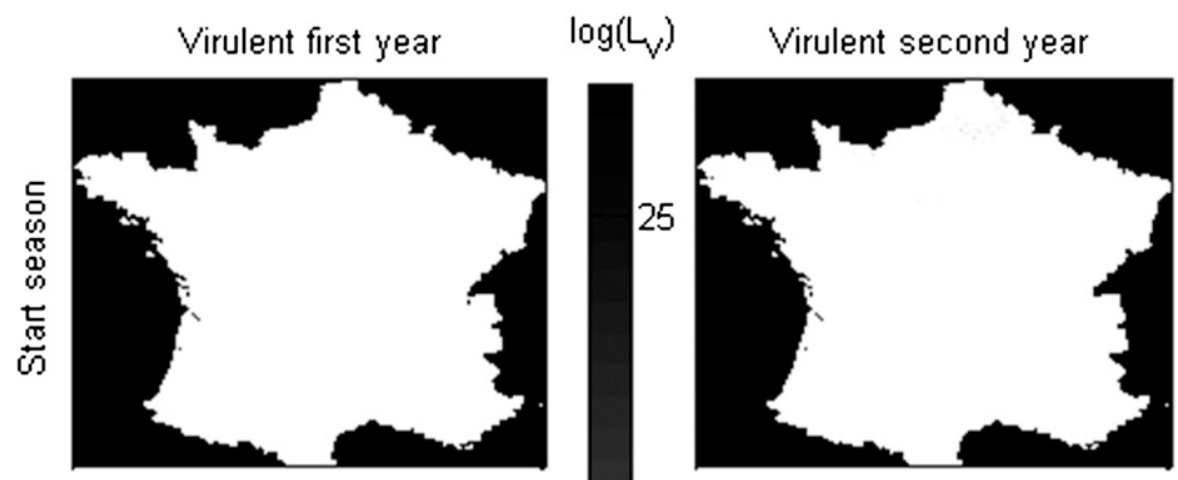

$\log \left(L_{V}\right)$

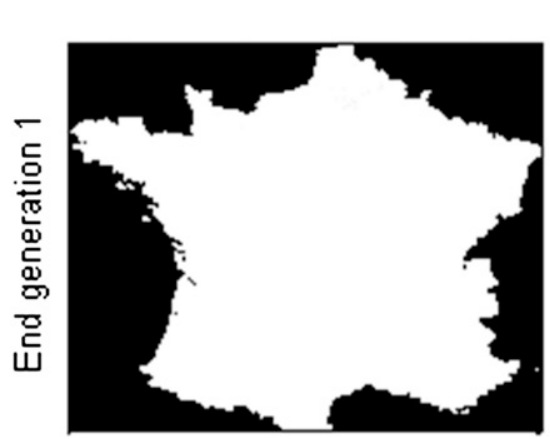

20
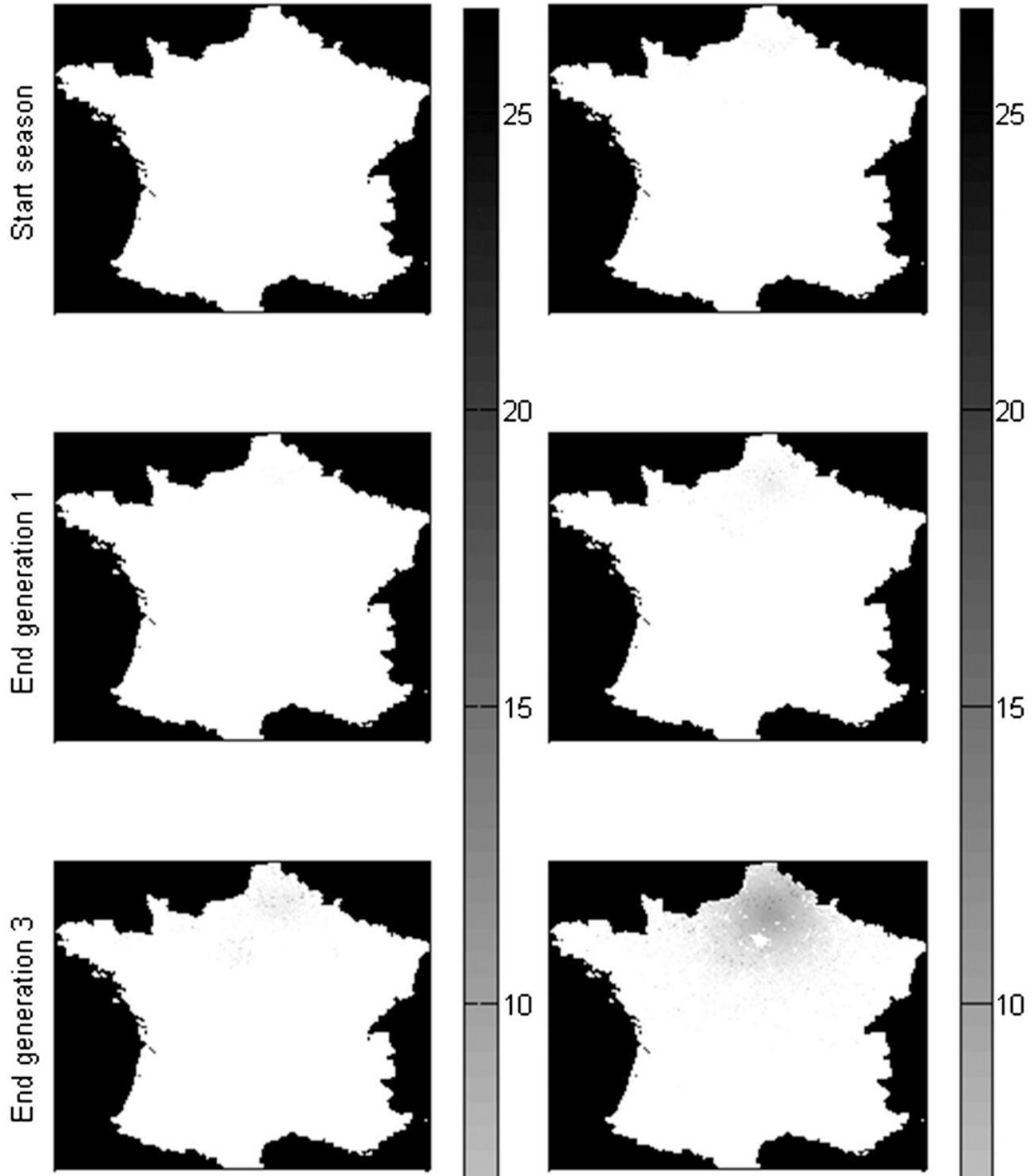

$-15$
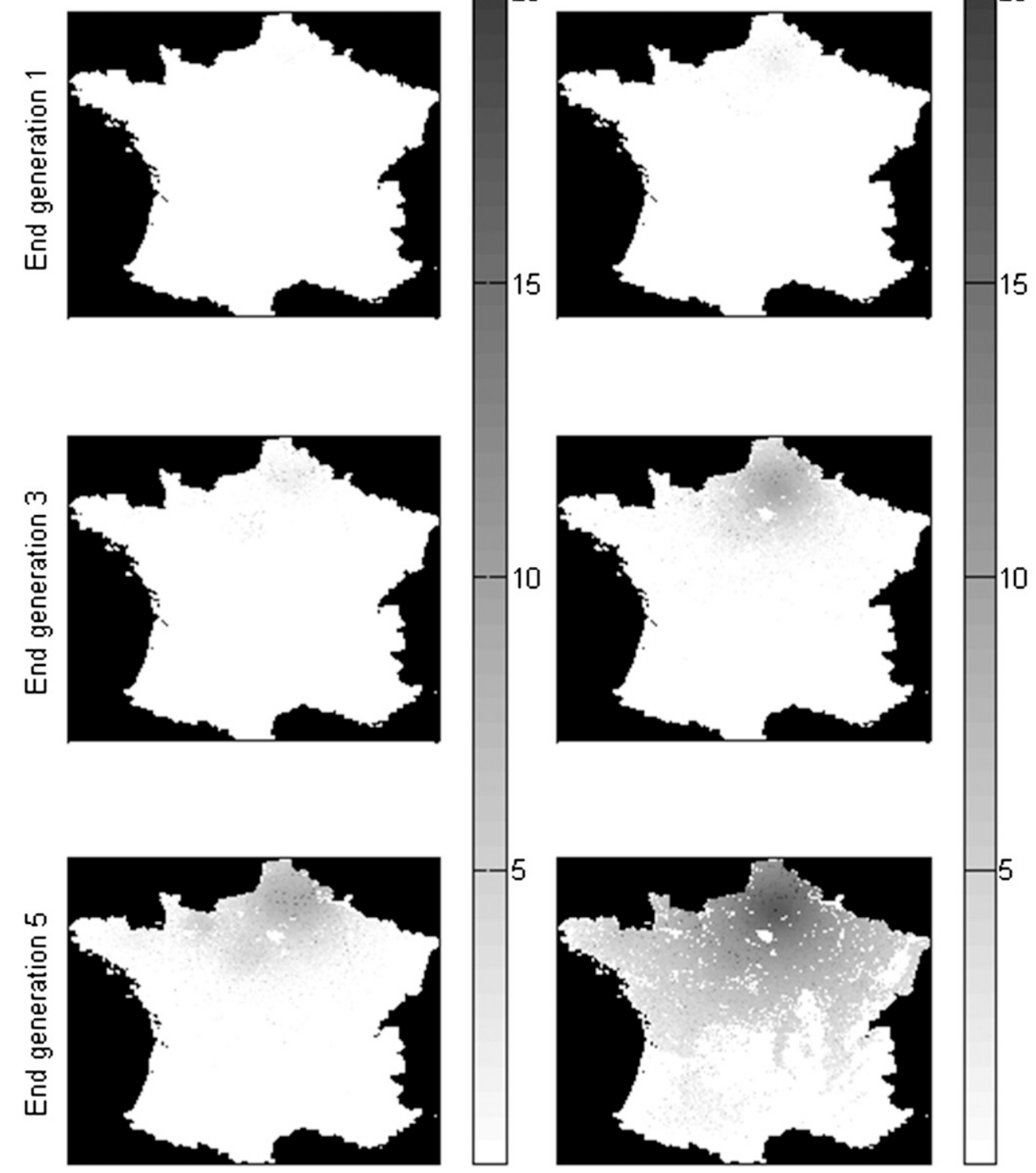

Fig. 2. Spatial and temporal dynamics of an virulent pathogen genotype in France depicted for the first 2 years of a simulation. Results are shown for sequential use with a fraction of single-resistant hosts $=0.6$. Shaded bar depicts the number of virulent lesions per field on a log scale; on this scale, 15 is approximately 13 virulent lesions $\mathrm{m}^{-2}$. 
(three replicates for each fraction of resistant fields ranging from 0.1 to 0.9 ), the pyramid of two resistance genes in one variety was never broken down. Furthermore, compared with virulence that was already present, the useful life was longer and deployment strategy had a much larger effect on the useful life (Fig. 3). The simulation results show that, for sequential use, crop rotation prolongs the useful life of resistance genes by 2 years, on average, when virulence is already present in the pathogen population at the introduction of the resistant variety, and by 10 years when virulence has to emerge by mutation (Fig. 3). Crop rotation reduces the amount of inoculum that survives between seasons. This results in a reduced total population size, which reduces the chance that a virulent genotype might emerge and be able to survive to the next season.

When virulent genotypes of the pathogen population had to emerge by stepwise mutation, a mixed strategy in which varieties with singlegene resistance and a variety with pyramid of (the same) two resistance genes are used concurrently, it greatly reduced the useful life of the double-resistant variety compared with a strategy in which the pyramid variety was grown without single-gene-resistant varieties (Fig. 3). Concurrent use of a stacked variety and two single-generesistant varieties facilitated the emergence of a resistance-breaking pathogen genotype for the pyramided variety, whereas sole use of the pyramid remained effective for more than 30 years. However, deploying a pyramided variety in a fraction of the resistant fields simultaneously with two single-gene-resistant varieties increased the useful life by 7 years, as compared with simultaneous use of only the two single-gene-resistant varieties. Therefore, introduction of a pyramid variety in the context of single-gene-resistant varieties increases the durability of resistance; however, maximum durability is achieved if the pyramid replaces all the single-gene-resistant varieties.

When four single-resistant varieties were grown simultaneously and virulence had to emerge by mutation, the useful life was highly variable (Fig. 4). The useful life of four resistance genes was longest when the cultivation of the variety with the broken resistance gene was continued (prolong strategy) (Fig. 4; Table 2). The reason for the positive effect on durability is that this variety, though susceptible for part of the population, is still effective to the rest of the pathogen genotypes. Hence, presence of this variety still reduces the overall size of the pathogen population and thereby limits the frequency of emergence of virulent pathogen genotypes.
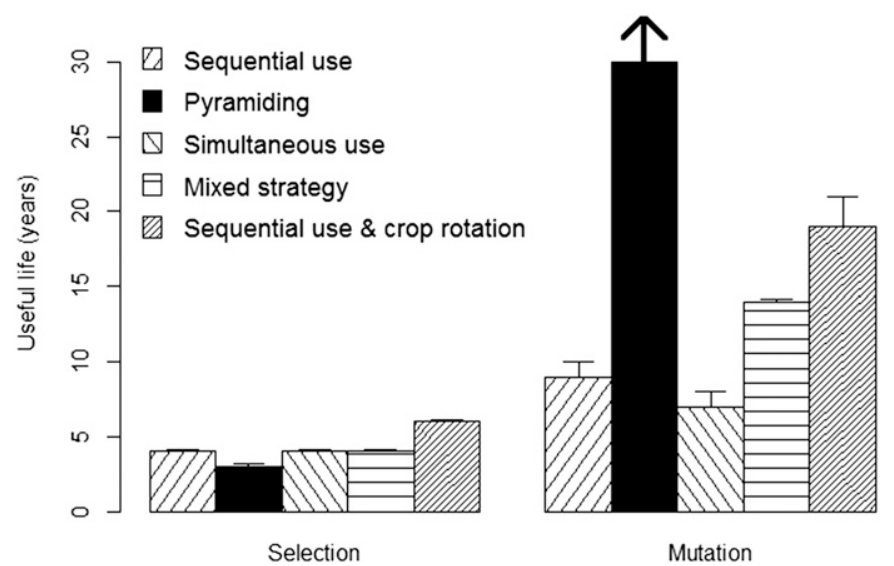

Fig. 3. Useful life (in years) for the deployment strategies of two resistance genes: (i) sequential use, (ii) pyramiding, (iii) simultaneous use, (iv) mixed strategy of two single-gene-resistant varieties together with a pyramided variety, and (v) sequential use in combination with crop rotation. The useful life for the selection case is depicted on the left and the useful life for the emergence by mutation case is depicted on the right. Note that, for the mutation case, the useful life for pyramiding is more than 30 years. Error bars represent one standard deviation from the mean. In all simulations, the total fraction of resistant hosts $=0.6$. For the depicted results of the mixed strategy, this was a mixture of 0.5 of the double-gene resistant variety and 0.05 of each singlegene-resistant variety.
The useful life for the prolong strategy was also higher, on average, than with sequential use of four resistance genes.

Continued use did select for increased complexity (i.e., genotypes with multiple virulence genes) because genotypes with two virulence genes have a bigger host range than genotypes with only one virulence gene and, thus, have a selective advantage. The host range increased with each added virulence gene. As a result, the pathogen population in the prolong scenario contained a higher fraction of pathogen genotypes with two or more virulence genes after 30 years than in the situation where a variety with broken-down resistance was removed and the remaining resistant varieties were redistributed (Fig. 5). Furthermore, in the prolong scenario, the selection for genotypes with three or four genotypes continued whereas, in the remove and replace scenario, a steady state was reached after the resistance gene of the last resistant host was broken down. The useful life for management strategies remove and replace or remove and redistribute were lower, on average, than for sequential use of four singlegene-resistant varieties.

For all tested deployment strategies, we found that the useful life of a resistance gene decreased when the fraction of resistant host in the landscape increased (Fig. 4). Thus, there was a trade-off between the area on which a gene was used and the useful life of this resistance gene.

\section{DISCUSSION}

Deployment strategy affected useful life of a resistance gene but only when virulence had to emerge by mutation. When virulence was

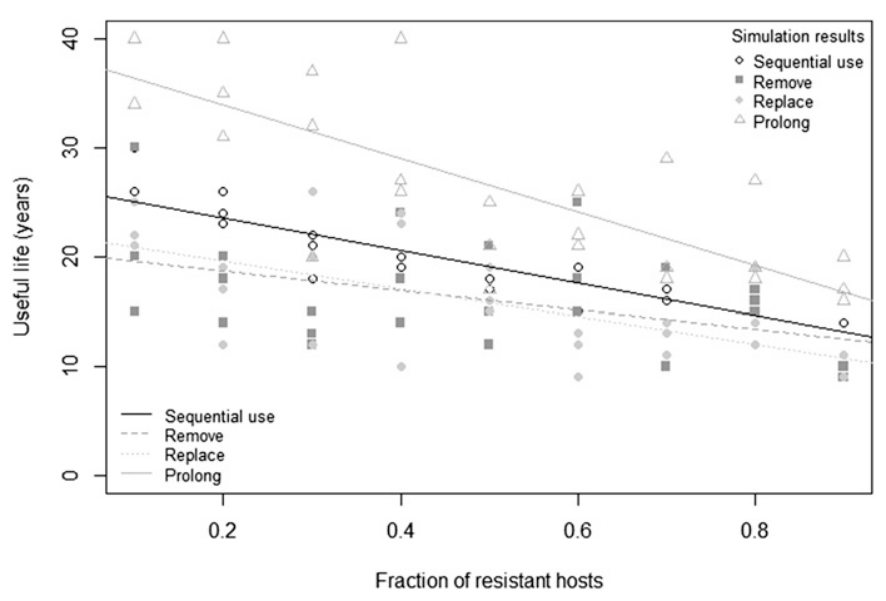

Fig. 4. Effect of fraction of resistant host and deployment strategy of four resistance genes on average useful life (in years) for three strategies for broken-down resistance when four single-gene-resistant varieties are used simultaneously. (i) Remove a broken-down variety and distribute the varieties that are still effective over all the resistant fields (solid squares and dark gray line). (ii) Replace a removed broken-down variety with a variety with a new resistance gene (solid diamond and light gray line). (iii) Prolong the use of a variety with broken-down resistance (open triangles and gray line). As a reference, the useful life for sequential use of four single-gene-resistant varieties is added (open circles and black line).

TABLE 2. Estimates for the linear model for the effect of deployment strategy (factor) and fraction of resistant host (denoted as FracR) on the total useful life of four single-gene-resistant varieties

\begin{tabular}{lrccc}
\hline Factor & Estimate & Standard error & $t$ value & $\operatorname{Pr}(>|t|)$ \\
\hline Intercept (fProlong) & 38.778 & 1.740 & 22.287 & $<2 \times 10^{-16}$ \\
fRemove & -18.259 & 2.461 & -7.420 & $3.92 \times 10^{-11}$ \\
fReplace & -16.630 & 2.461 & -6.758 & $9.44 \times 10^{-10}$ \\
fSequentialUse & -12.259 & 2.461 & -4.982 & $2.64 \times 10^{-06}$ \\
FracR & -24.444 & 3.092 & -7.906 & $3.62 \times 10^{-12}$ \\
fRemove:FracR & 15.556 & 4.373 & 3.557 & 0.000574 \\
fReplace:FracR & 11.778 & 4.373 & 2.693 & 0.008293 \\
fSequentialUse:FracR & 9.556 & 4.373 & 2.185 & 0.031203 \\
\hline
\end{tabular}


already present in a very small fraction of the population, durability was low in all deployment strategies and deployment strategy had no effect on useful life. When virulence had to evolve by mutation, pyramiding was the most durable deployment strategy. A doublegene-resistant variety did not break down within 30 years. This is much longer than found in practice for yellow rust in wheat (Bayles et al. 2000; de Vallavieille-Pope et al. 2012). This discrepancy could be explained by the use of the mixed strategy in practice. Pyramid varieties are cultivated alongside single-gene and susceptible varieties, thus increasing the size of the pathogen population with single virulence genes that, step by step, become multivirulent by a single mutation and break the pyramid's resistance. In our simulations, we considered the introduction of a variety with a pyramid of two new previously unused resistance genes whereas, in practice, new resistance genes are first introduced in single-gene-resistant varieties and then stacked in one variety (de Vallavieille-Pope et al. 2012). Therefore, at the introduction of the variety with stacked resistance genes, a part of the pathogen population will be virulent on at least one of the stacked resistance genes. This greatly increases the chance that a pathogen genotype virulent on both resistance genes will emerge; as a result, the useful life of a pyramid is much shorter in practice than if it had been introduced as one variety with two stacked resistance genes that were previously unused.

In contrast to simultaneous use of two single-gene-resistant varieties, the simulation with simultaneous use of four single-gene-resistant varieties showed that, when the deployment of varieties was continued after the resistance was broken down, the useful life of the four resistance genes was longer than with sequential use. Only in this deployment scenario was a broken-down variety still effective against part of the pathogen population; namely, the pathogen genotypes that have a single virulence gene for another resistance gene. In this deployment scenario, all virulent pathogen genotypes were slowed down in their per capita growth, resulting in a smaller pathogen population size. This finding indicates that the durable life of resistance genes can also be prolonged in the current practice if multiple single-generesistant varieties are used simultaneously, as long as the use of varieties is continued after resistance is broken down.

We developed a spatial model that can be used to test spatial deployment tactics. Because the pathogen can disperse over long distances, we ran some preliminary tests with a very coarse-scaled spatial deployment. In these simulations, four single-gene-resistant varieties were deployed in bands parallel to the northwest coast, and a broken-down variety was replaced by a not previously used resistant variety (i.e., remove and replace). In these simulations, the resistant varieties that were deployed in the northwest of France broke down multiple times, whereas the other varieties that were deployed only in the southern part of France did not break down in the period until four resistance genes were broken down (results not shown). Keeping in mind that the northwest of France is the area where the most wheat is produced, faster breaking down of resistance in that area might not be desirable. To find the optimal spatial deployment strategy would require further study.

In this study, we compared the effect of deployment strategy in two fundamentally different situations; one in which virulence was already present and a second in which virulence had to emerge by mutation. A third relevant situation (not tested here) would be immigration. This could potentially give a different outcome than a scenario of mutation. In an immigration scenario, the resistance-breaking genotypes come from outside, regardless of the deployment strategy and regardless of the population size of the avirulent genotype; whereas, in the mutation scenario, the number of newly emerging resistance-breaking genotypes constitute a fraction of the population produced on susceptible genotypes. In this study, we showed that the apparent seasonal spread of the virulent genotype was mainly caused by new mutations. Moreover, the largest fraction of spores produced by a mutant lesion remained in the field where it was produced. Therefore, the effect of resistance-breaking spores that arrived due to immigration is likely to be local. Data from France showed occasions where a new genotype arrived after a disease-free year but other changes in phenotype distributions have been more gradual. How immigration affects the durable life of the deployment strategies is worth investigating further.

Similar to what van den Bosch et al. (2014) and Milgroom and Fry (1988) found for selection for fungicide-resistant strains, we found that a reduction of the initial frequency of virulence (fungicide resistance) had a positive effect on the useful life. When virulence had to emerge by mutation, stacking two resistance genes was much more effective than using two single-gene-resistant varieties in sequence or simultaneously. There are also marked similarities between our results and the case of emergence and the evolution of insects able to feed on transgenic plants expressing one or two
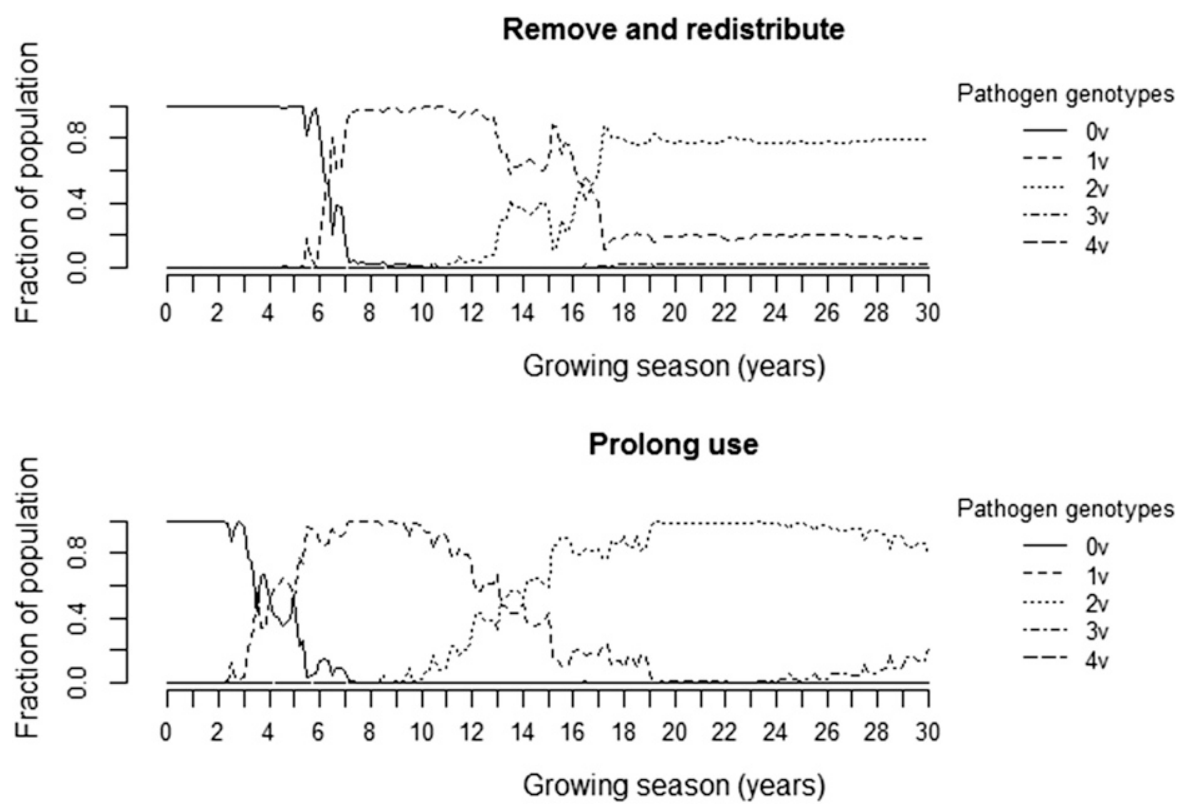

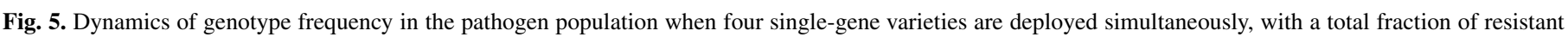

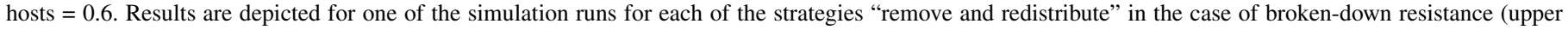
panel) and "prolong use" in the case of broken-down resistance (lower panel). 
Bacillus thuringienis toxins (Bates et al. 2005; Roush 1998; Zhao et al. 2003, 2005), even though P. striiformis is dikaryotic, with two haploid nuclei in the urediniospores, and needs only one or two mutations to become virulent on one resistance gene, whereas insects are diploid and need to be homozygote for $B$. thuringienis resistance to be able to feed on $B$. thuringienis crops. The superiority of pyramiding over the other deployment strategies and the eroding effect of placing single-gene varieties together with a pyramided variety both in resistance to pathogens and in $B$. thuringienis crops results from the fact that a double-virulent pathogen genotype or double-resistant insect genotype has to emerge by stepwise mutation. The single-gene varieties serve as stepping stones for the emergence of pathogen genotypes with two virulence genes, or insect genotypes that are resistant to two toxins in case of B. thuringienis (Zhao et al. 2005).

From a management perspective, planting pyramided varieties concurrently with single-gene-resistant plants should be avoided whenever possible and practicable. There is currently no regulation for the use of resistance genes. Durable use of resistance genes will require collaboration between breeders to collectively not use resistance genes in varieties until these genes can be pyramided to prolong durable life. However, there is only an advantage to waiting if the virulence genes are not yet present in the population and need to emerge by mutation. If they are already present, or if multiplevirulent genotypes can immigrate by national or intercontinental dispersal, withholding use of single resistance genes may have no benefit. Therefore, it is very important to find out whether previous resistance breaking was through selection, mutation, or transnational dispersal. Furthermore, voluntary collaboration between breeders may be very difficult to achieve because such a system is vulnerable to "free riders" (Rand and Nowak 2013). As such, the deployment of resistance genes in agricultural practice is an example of the "tragedy of the commons" (Hardin 1968).

Similar to variety mixtures in which several single-gene varieties are planted simultaneously in a field, we found that simultaneous use reduced the total pathogen population size. In our case, disease was not controlled through dilution of inoculum within a field, as described by Wolfe (1985) for variety mixtures, but at a national scale. Mundt (2014) suggested that diversity in the fields reduces the number of new founders originating from other fields (in a sense, dilution of inoculum between fields) and that the infection rates within a field are relatively unaffected by the variety mixtures. Autoinfection (infection by inoculum produced on the same host unit) may play an important role in infection rates within a field (Mundt 2009). Reduction in the number of new founders is most likely also the mechanism for the reduced total population size with simultaneous growth.

Mutations to virulence frequently occurred in our simulations. Nevertheless, the spread of newly emerged virulent phenotypes was initially low because a large fraction of the virulent spores that are produced by the new virulent lesion will remain in the field of origin. On the other hand, the initial avirulent population was large and rapidly spread over the country. After arrival in a new field, the population initially grew geometrically. The chance of a resistancebreaking mutation increases when the avirulent population is larger. We found that new mutations are the driving factor behind the apparent spread of the virulent phenotype in the first year. This indicates that the chance that a virulent phenotype emerges can be reduced when the avirulent population is kept small, either by control measures or by reducing the year-to-year survival (as is the case for crop rotation, or eradication of wheat offsprings). We found that crop rotation prolongs the useful life of resistance genes, especially when virulence has to emerge by mutation (Fig. 3). Crop rotation reduced the total population size and, therefore, the chance that a virulent genotype would emerge and settle was lower.

Variety choice and spatial deployment of varieties are preventive tactics that are the basis of an integrated pest management strategy (Kogan 1998). Resistance in plants cannot protect the crop from disease forever. Therefore, the use of resistant varieties always needs to be combined with other measures. Responsible use of fungicides can potentially prolong the useful life of resistance genes by reducing the pathogen population size during a growing season. Crop rotation has a similar effect; it reduces the total population size at the start of a new growing season and, therefore, slows down the emergence of a virulent genotype. We showed that crop rotation is also effective for a pathogen that disperses over long distances. Useful life and effectiveness of qualitative resistance could also be prolonged if these would be combined with quantitative resistance, which slows down selection once the qualitative resistance gene is broken down (Mundt 2014).

In conclusion, our results showed that durable life can be enhanced by the deployment strategy. However, none of the tested gene deployment scenarios provided permanent effectiveness. Simulation results from the spatial explicit model in a realistic setting showed that, when a certain virulence gene is already present in a very small fraction of the pathogen population, the useful life of a resistance gene is generally low. When virulence has to arise by mutation, pyramiding of two or more new resistance genes is the most durable deployment strategy. However, using single-gene-resistant varieties together with pyramided varieties breaks down the effectiveness of the pyramided variety and reduces the useful life. Simulation results showed that continued use of varieties with broken-down resistance when multiple single-gene-resistant varieties were deployed simultaneously enhanced durable life of resistance genes as compared with sequential use. In this case, the variety with broken-down resistance was still effective against part of the pathogen population that is virulent on the other resistant varieties. These results provide guidance on effective strategies for using resistance genes in crop protection practice and demonstrate the need to know whether resistance breaking is due to selection or emergence. Using the above findings in practice could have major benefits for sustainable use of plant resistance genes but effective deployment of resistance genes requires collaboration between stakeholders, industry, breeders, and farmers.

\section{ACKNOWLEDGMENTS}

The research leading to these results has received funding from the European Union Seventh Framework Programme (FP7/ 2007-2013) under grant agreement number 265865-PURE. We thank F. van den Bosch, F. van den Berg, M. Leconte, and M. Hovmoller for stimulating discussion.

\section{LITERATURE CITED}

Abawi, G. S., and Widmer, T. L. 2000. Impact of soil health management practices on soilborne pathogens, nematodes and root diseases of vegetable crops. Appl. Soil Ecol. 15:37-47.

Agreste. 2013. Statistique agricole annuelle, percentage wheat used per department from 1989 to 2013 obtained from Philippe du Cheyron (ArvalisInstitut du Végétal). Online publication. Ministère de l'agriculture, de l'agroalimentaire et de la forêt. http://agreste.agriculture.gouv.fr/enquetes/ statistique-agricole-annuelle-saa/

Bahri, B., Kaltz, O., Leconte, M., de Vallavieille-Pope, C., and Enjalbert, J. 2009. Tracking costs of virulence in natural populations of the wheat pathogen, Puccinia striiformis f. sp. tritici. BMC Evol. Biol. 9:26.

Bates, S. L., Zhao, J.-Z., Roush, R. T., and Shelton, A. M. 2005. Insect resistance management in GM crops: Past, present and future. Nat. Biotechnol. 23:57-62.

Bayles, R. A., Flath, K., Hovmøller, M. S., and de Vallavieille-Pope, C. 2000. Breakdown of the $\mathrm{Yr} 17$ resistance to yellow rust of wheat in northern Europe. Agronomie 20:805-811.

Brown, J. K. M., and Hovmøller, M. S. 2002. Aerial dispersal of fungi on the global and continental scales and its consequences for plant disease. Science 297:537-541.

Clark, J. S., Silman, M., Kern, R., Macklin, E., and HilleRisLambers, J. 1999. Seed dispersal near and far: Patterns across temperate and tropical forests. Ecology 80:1475-1494.

de Vallavieille-Pope, C., Ali, S., Leconte, M., Enjalbert, J., Delos, M., and Rouzet, J. 2012. Virulence dynamics and regional structuring of Puccinia striiformis f. sp. tritici in France between 1984 and 2009. Plant Dis. 96:131-140. 
De Wit, P. J. G. M. 1997. Pathogen avirulence and plant resistance: A key role for recognition. Trends Plant Sci. 2:452-458.

European Environment Agency. 2012. Corine Land Cover 2006 raster data. Online publication. http://www.eea.europa.eu/data-and-maps/data/corine-landcover-2006-raster-2

Flor, H. H. 1971. Current status of the gene-for-gene concept. Annu. Rev. Phytopathol. 9:275-296.

Hardin, G. 1968. The tragedy of the commons. Science 162:1243-1248.

Hovmøller, M. S., Justensen, A. F., and Brown, J. K. M. 2002. Clonality and long-distance migration of Puccinia striiformis $\mathrm{f}$. sp. tritici in north-west Europe. Plant Pathol. 51:24-32.

Kiyosawa, S. 1982. Genetics and epidemiological modeling of breakdown op plant disease resistance. Annu. Rev. Phytopathol. 20:93-117.

Kogan, M. 1998. Integrated pest management: Historical perspectives and contemporary developments. Annu. Rev. Entomol. 43:243-70.

Kolmer, J. A. 1996. Genetics of resistance to wheat leaf rust. Annu. Rev. Phytopathol. 34:435-455.

Leach, J. E., Vera Cruz, M. C., Bai, J., and Leung, H. 2001. Pathogen fitness penalty as a predictor of a durability of disease resistance genes. Annu. Rev. Phytopathol. 39:187-224.

Leonard, K. J., and Czochor, R. J. 1980. Theory of genetic interactions among populations of plants and their pathogens. Annu. Rev. Phytopathol. 18:237258.

McDonald, B. A., and Linde, C. 2002. Pathogen population genetics, evolutionary potential, and durable resistance. Annu. Rev. Phytopathol. 40: 349-379.

Milgroom, M. G., and Fry, W. E. 1988. A simulation analysis of the epidemiological principles for fungicide resistance management in pathogen populations. Phytopathology 78:565-570.

Milus, E. A., Kristensen, K., and Hovmøller, M. S. 2009. Evidence for increased aggressiveness in a recent widespread strain of Puccinia striiformis f. sp. tritici causing stripe rust of wheat. Phytopathology 99:89-94.

Mundt, C. C. 2009. Importance of autoinfection to the epidemiology of polycyclic foliar disease. Phytopathology 99:1116-1120.

Mundt, C. C. 2014. Durable resistance: A key to sustainable management of pathogens and pests. Infect. Genet. Evol. 27:446-455.

Mundt, C. C., Cowger, C., and Garrett, K. A. 2002. Relevance of integrated disease management to resistance durability. Euphytica 124:245-252.

Neubert, M. G., Kot, M., and Lewis, M. A. 1995. Dispersal and pattern formation in a discrete-time predator-prey model. Theor. Popul. Biol. 48:7-43.

Parlevliet, J. E. 1981. Stabilizing selection in crop pathosystems: An empty concept or a reality? Euphytica 30:259-269.

Parlevliet, J. E. 2002. Durability of resistance against fungal, bacterial and viral pathogens; present situation. Euphytica 124:147-156.

Powell, J. 2001. Spatio-temporal models in ecology: An introduction to integro-difference equations. Online publication. http://www.math.usu.edu/ powell/wauclass/labs.html

Powell, J., McMillen, T., and White, P. 1998. Connecting a chemotactic model for mass attack to a rapid integro-difference emulation strategy. SIAM J. Appl. Math. 59:547-572.
Rand, D. G., and Nowak, M. A. 2013. Human cooperation. Trends Cogn. Sci. 17:413-425.

Rapilly, F. 1979. Yellow rust epidemiology. Annu. Rev. Phytopathol. 17:59-73.

Robinet, C., Kehlenbeck, H., Kriticos, D. J., Baker, R. H. A., Battisti, A., Brunel, S., Dupin, M., Eyre, D., Faccoli, M., Ilieva, Z., Kenis, M., Knight, J., Reynaud, P., Yart, A., and van der Werf, W. 2012. A suite of models to support the quantitative assessment of spread in pest risk analysis. PLoS One 7:e43366.

Roush, R. T. 1998. Two-toxin strategies for management of insecticidal transgenic crops: Can pyramiding succeed where pesticide mixtures have not? Philos. Trans. R. Soc. B. 353:1777-1786.

Sapoukhina, N., Durel, C.-E., and Le Cam, B. 2009. Spatial deployment of gene-for-gene resistance governs evolution and spread of pathogen populations. Theor. Ecol. 2:229-238.

Sapoukhina, N., Tyutyunov, Y., Sache, I., and Arditi, R. 2010. Spatially mixed crops to control the stratified dispersal of airborne fungal diseases. Ecol. Modell. 221:2793-2800.

Skelsey, P., Rossing, W. A. H., Kessel, G. J. T., and van der Werf, W. 2010. Invasion of Phytophthora infestans at the landscape level: How do spatial scale and weather modulate the consequences of spatial heterogeneity in host resistance? Phytopathology 100:1146-1161.

Stuckenbrock, E. H., and McDonald, B. A. 2008. The origins of plant pathogens in agroecosystems. Annu. Rev. Phytopathol. 46:75-100.

Trivedi, P. C., and Barker, K. R. 1986. Management of nematodes by cultural practices. Nematropica 16:213-236.

van den Bosch, F., Oliver, R., van den Berg, F., and Paveley, N. 2014. Governing principles can guide fungicide-resistance management tactics. Annu. Rev. Phytopathol. 52:175-195.

Van der Plank, J. E. 1968. Disease Resistance in Plants. Academic Press, New York and London.

Wolfe, M. S. 1985. The current status and prospects of multiline cultivars and variety mixtures for disease resistance. Annu. Rev. Phytopathol. 23:251-273.

Wolfe, M. S., and Barrett, J. A. 1977. Population genetics of powdery mildew epidemics. Ann. N. Y. Acad. Sci. 287:151-163.

Wolfe, M. S., and McDermott, J. M. 1994. Population genetics of plant pathogen interactions: The example of Erysiphe graminis-Hordeum vulgare pathosystem. Annu. Rev. Phytopathol. 32:89-113.

Zadoks, J. C. 1961. Yellow rust on wheat, studies in epidemiology and physiologic specialization. Tijdschr. Plantenziekten 67:69-256.

Zhan, J., Thrall, P. H., and Burdon, J. J. 2014. Achieving sustainable plant disease management through evolutionary principles. Trend Plant Sci. 19: $570-575$.

Zhao, J. Z., Cao, J., Collins, H. L., Bates, S. L., Roush, R. T., Earle, E. D., and Shelton, A. M. 2005. Concurrent use of transgenic plants expressing a single and two Bacillus thuringiensis genes speeds insect adaptation to pyramided plants. Proc. Natl. Acad. Sci. USA 102:8426-8430.

Zhao, J.-Z., Cao, J., Li, Y., Collins, H. L., Roush, R. T., Earle, E. D., and Shelton, A. M. 2003. Transgenic plants expressing two Bacillus thuringiensis toxins delay insect resistance evolution. Nat. Biotechnol. 21: 1493-1497. 